\title{
DISTANCE LEARNING OF "UKRAINIAN LANGUAGE (BY PROFESSIONAL DIRECTION)” OF STUDENTS OF MEDICAL SPECIALTIES
}

І. Я. Заліпська

Тернопільський національний медичний університет імені І. Я. Горбачевського МОЗ Украӥни ДИСТАНЦЙНЕ НАВЧАННЯ ДИСЦИПЛІНИ УКРАЇНСЬКА МОВА (ЗА ПРОФЕСІЙНИМ СПРЯМУВАННЯМ)» СТУДЕНТІВ МЕДИЧНИХ СПЕЦІАЛЬНОСТЕЙ

\begin{abstract}
The article considers the features and benefits of using distance learning in the educational process. The content of the concept of "distance learning" and the views of scientists on its interpretation are presented. It reveals the teaching experience of the discipline "Ukrainian language (by professional direction)” by means of distance learning at the Ukrainian Language Department of I. Horbachevsky Ternopil National Medical University. The materials for checking the level of medical specialties students' knowledge in the aforementioned discipline are offered for the following themes: "Language standard. Orthoepic norms, norms of emphasis", "Lexical aspect of medical professional language. Phraseological units in professional language”, "Terminology in professional communication. Lexical-semantic relations in scientific terminology. Features of Ukrainian medical terminology", "Dictionaries in professional communication. Types of dictionaries, their function and role in enhancing language culture", "Morphological aspect of Medical Professional Language", "Syntactic aspect of Medical Professional Language”, "Features of Ukrainian language etiquette. Communicative qualities of language culture. Doctor's Language Etiquette”, "Public speech and its genres".

It emphasizes the usage of detailed instructions for practical tasks and for submitting samples to each task. The research demonstrates that the teacher must take into account the goal, the age of the students, the professional orientation of the tasks. It underscores that the given tasks have a practical orientation and cannot comprehensively assess the student's knowledge level in the study of a specific topic, but they aim to diversify distance learning, make it interesting. Undoubtedly, the usage of computer-based distance learning provides a learning process, so it needs to be refined and developed. This type of training encourages the specialist to look for new forms and methods of teaching the discipline, and the student to work independently, to work with different sources of information. It should be noted that the development of distance learning in the Ukrainian education system is perspective.
\end{abstract}

Key words: distance learning; Ukrainian language (by professional direction); higher medical educational establishment; practical lesson; professional language.

Анотація. У статті висвітлено особливості та переваги використання дистанційного навчання в освітньому процесі. Репрезентовано зміст поняття «дистанційне навчання», представлено погляди науковців на його тлумачення. Розкрито досвід викладання дисципліни «Українська мова (за професійним спрямуванням)» засобами дистанційного навчання на кафедрі української мови Тернопільського національного медичного університету імені І. Я. Горбачевського МОЗ України. Запропоновано матеріали для перевірки рівня знань студентів медичних спеціальностей із вищезазначеної дисципліни до таких тем: «Мовна норма. Орфоепічні норми, норми наголосу», «Лексичний аспект медичної професійної мови. Фразеологізовані одиниці у фаховій мові», «Термінологія у професійному спілкуванні. Лексико-семантичні відношення в науковій термінології. Особливості української медичної термінології», «Словники в професійному спілкуванні. Типи словників, їх функція та роль у підвищенні мовної культури», «Морфологічний аспект медичної професійної мови», «Синтаксичний аспект медичної професійної мови», «Особливості українського мовного етикету. Комунікативні якості культури мови. Мовний етикет лікаря», «Публічний виступ та його жанри».

Наголошено на використанні детальної інструкції для виконання практичних завдань та поданні зразків до кожного завдання. Встановлено, що під час розроблення завдань для студента викладач повинен обов'язково враховувати поставлену мету, вік студентів, фахову спрямованість завдань. Зазначено, що наведені завдання мають практичне спрямування і не можуть комплексно оцінювати рівень знань студента із вивчення конкретної теми, проте вони мають на меті урізноманітнити дистанційне навчання, зробити його цікавим. Безперечно, використання дистанційного навчання за допомогою комп’ютерних технологій забезпечує процес навчання, тому його потрібно вдосконалювати і розвивати. Такий вид навчання спонукає фахівця до пошуку нових форм та методів викладання дисципліни, а студента до самостійної роботи, до роботи з різними джерелами інформації. Вважаємо розвиток дистанційного навчання у системі української освіти перспективним.

Ключові слова: дистанційне навчання; українська мова (за професійним спрямуванням); вищий медичний заклад освіти; практичне завдання; фахова мова.

(C) I. Ya. Zalipska 


\section{Materials of International Scientific and Practical Conference \\ "PROFESSIONAL AND COMMUNICATION CULTURE OF THE FUTURE DOCTOR: LINGUISTIC, PEDAGOGICAL AND PHILOSOPHICAL ASPECTS”}

Introduction. Today the educational process is actively changing. A new stage of its development has come, when information processes become one of the most important components of human life. Due to this, education is looking for new forms of organization of the educational process. We see such a wave of change especially in the higher education system.

As noted by L. M. Unhuryan, H. V. Chernetska, I. A. Naumenko, it is undergoing major changes that lead to the improvement and emergence of new educational technologies [5]. According to L. V. Stykhno, the global processes taking place in the modern world are becoming a catalyst for the transformation of the traditional education system. The activities of most educational institutions are reorganized in line with the development and usage of information technology in the dissemination of knowledge, which is one of the main tasks of improving the quality of education in the 21st century. The result is the formation of a single educational space and a global market for educational services [7].

I. Horbachevsky Ternopil National Medical University (TNMU) offers a wide range of services for the entrant. There are four faculties in the higher educational establishment: medical, pharmaceutical, dental and faculty of foreign students. In accordance with the higher education standard of the second (master's) level of preparation of higher education applicants at TNMU students study the discipline "Ukrainian language (by professional direction)". It has 90 hours and students usually have "Ukrainian language (by professional direction)" at the first year of studying during one semester.

During their study, medical students must have mastered: the basics of the culture of speech; rules of communication with the participants of production processes, using standardized principles of professional communication at the level of modern literary Ukrainian language; syntactic norms of modern Ukrainian language in professional and business oral and written communication; stylistic structure of language; basic rules of using dictionaries; linguistic features of scientific and official-business styles; classification of Ukrainian terminology; basic principles and models of word formation of medical terms in Ukrainian language; rules for making up the most common types of business documents.

We are accustomed to the traditional form of teaching medical students - full-time. However, given the diverse circumstances, challenges to society, teachers must also be prepared for distance learning. At the legislative level, there is an order of the Ministry of Education and Science of Ukraine "On approval of the Regulations on distance learning” [4], according to which all its conditions are presented.

According to L. V. Stykhno, the main prerequisite for Ukraine's accession to a single European educational space is the introduction of a credit-module system for organizing the educational process, which involves strengthening the role of students' independent work. The most effective solution to these problems is facilitated by distance learning, which is carried out on the basis of modern pedagogical, information, computer and telecommunication technologies. This form of learning organization will solve many problems that other forms of education are powerless. These problems affect a large number of citizens of any country, including Ukraine, especially - to get your first or second higher education, to improve your qualification, to exchange experience, to get specialist advice, to participate actively in professional communication without leaving your family or work [7].

Analysis of sources on the research problem shows the considerable interest of national and foreign scientists in the modern education development. For example, V. G. Hasson, E. K. Waterman publish "Criteria for the quality of distance education" [6], A. Veremchuk - "Problems and prospects of distance learning in universities” [1], V. M. Prybylova "Problems and advantages of distance learning in higher educational establishments of Ukraine” [3], L. V. Stykhno - "Distance learning as a perspective direction of development of modern education" [7], M. Yu. Kademiya, V. O. Umanets - "Distance learning in a virtual university as a way of access to quality education" [2].

Scientists are researching ways to increase the effectiveness of training using information technology; conceptual pedagogical provisions on distance learning; quality criteria for distance learning; problems and benefits of distance learning; perspectives for its development, etc. Despite the large amount of research, we are experiencing a lack of practical scientific studies in specific fields of knowledge.

The aim - to analyze and offer up-to-date materials for practical training in the discipline "Ukrainian language (by professional direction)" for medical students during distance learning. 


\section{Materials of International Scientific and Practical Conference \\ "PROFESSIONAL AND COMMUNICATION CULTURE OF THE FUTURE DOCTOR: LINGUISTIC, PEDAGOGICAL AND PHILOSOPHICAL ASPECTS”}

Methods. The specificity of the subject under study has necessitated the use of a number of methods: direct observation; descriptive method; method of complex analysis.

Results. Today, there are many approaches to defining the concept of "distance learning". This concept was formulated by scholars such as M. Thompson, M. Moore, A. Clark, and D. Keegan. Each of these authors emphasized a separate aspect of this method [6]. A. Veremchuk under distance learning understands the form of teaching with using computer and telecommunication technologies, which provide interactive cooperation of teachers and students at different stages of learning and independent work with the materials of information network [1] L. V. Stykhno adds to this definition: "It is an ideal solution for those who prefer modern information technology in education and value their time. Distance learning provides students with 24/7 access to course materials, ongoing support and teacher advice and methodologists, online video lectures, virtual simulators and other technology solutions for ensuring an effective learning process" [7].

More detailed definition is given by the authors in the article "Distance learning of part-time students of the Faculty of Pharmacy at a medical university": "Distance learning is a very flexible system, it allows all participants of the educational process (students, teachers and administrators of the educational institution) to choose a convenient time for classes. This system allows you to acquire the necessary skills and new knowledge through a personal computer (PC) and access to the Internet. The location of the PC is irrelevant, so you can study at home, at work, and anywhere else with a PC with Internet access" [5].

During distance learning, it is also important to select tasks for students who are relevant, up-to-date, timely, who may be of interest to the student and thus contribute to better assimilation of material, better student contact with the teacher. The teacher, in turn, should use modern technical means of teaching and mobile applications, to facilitate the perception of new material, to perform the tasks set before the student.

TNMU medical students study "Ukrainian language (by professional direction)" in 15 practical classes: "Theme 1. Modern Ukrainian as a means of professional communication”, “Theme 2. Ukrainian language: history and modernity", "Theme 3. Language standard. Orthoepic norms, norms of emphasis”, "Theme 4.
Lexical aspect of medical professional language. Phraseological units in professional language", "Theme 5. Terminology in professional communication. Lexical-semantic relations in scientific terminology. Features of Ukrainian medical terminology”, "Theme 6. Dictionaries in professional communication. Types of dictionaries, their function and role in enhancing language culture", "Theme 7. Morphological aspect of Medical Professional Language”, "Theme 8. Syntactic aspect of Medical Professional Language", "Theme 9. Features of Ukrainian language etiquette. Communicative qualities of language culture. Doctor's Language Etiquette", "Theme 10. Public speech and its genres", "Theme 11. The stylistic aspect of medical professional language”, "Theme 12. Scientific style in the professional language. Structure and types of scientific text", "Theme 13. The culture of written business language: a general characteristic", "Theme 14. Requirements for preparation and registration of administrative-clerical documents", "Theme 15. Professional documentation of medical professionals. Features of its assembly and design".

We offer to pay attention to the following types of work during the study of "Ukrainian language (by professional direction)" by students of medical specialties.

"Theme. Language standard. Orthoepic norms, norms of emphasis": Listen to a video fragment (up to 5 minutes) and find the pronunciation mistakes in it and suggest the correct variant.

"Theme. Lexical aspect of medical professional language. Phraseological units in professional language”: Task 1. Analyze the meaning of the words "cancer" ("рак”), "туосаrdial infarction” (“інфаркт міокарда”), “раndemic” (“пандемія”) in online publications. Make a PrintScreen of each example. Task 2. Make up a dialogue between the doctor and the patient. Use 10 idioms of medical sphere. Teacher can recommend another medical terms or can give examples of medical idioms.

"Theme. Terminology in professional communication. Lexical-semantic relations in scientific terminology. Features of Ukrainian medical terminology": Task 1. In online sources find synonyms for words "Acquired Immune Deficiency Syndrome" ("синдром набутого імунодефіциту”), “influenza” (“грип”), "leukaemia” (“лейкемія”). Make a PrintScreen of each example. Task 2. In online sources find antonyms for words "to absorb" (“абсорбувати”), "to breath 
in” (“вдихати”), “to clog” (“закупорювати”). Make a PrintScreen of each example.

"Theme. Dictionaries in professional communication. Types of dictionaries, their function and role in enhancing language culture": Task 1. Check out the sites:

1. http://www.lcorp.ulif.org.ua/dictua/

2. http://www.mova.info

3. http://www.sum.in.ua/

4. http://www.slovnyk.ua

5. http:// www.rozum.org.ua/

6. http://slovopedia.org.ua/

In what dictionaries (on which sites) can you find the lexemes "abscess" ("абсцес"), "fracture” (перелом), "self-isolation” (“самоізоляція”), “COVID-19”? What can you check for these dictionaries? Task 2. What mobile applications do you use to enhance your professional language culture? What are the words you often search for in these applications?

"Theme. Morphological aspect of Medical Professional Language": Task 1. Read the proposed fragment from online sources. Is the grammatical (morphological, syntactic and word-forming) norm correct in the text? Edit grammar mistakes.

"Theme. Syntactic aspect of Medical Professional Language": Task 1. Find fragments of medical themes with syntax violations in online sources. Select the fragments you want to edit and make a PrintScreen of each example. Task 2. Find in the Internet 5 complex sentences with the word "coronavirus" ("коронавірус") or "COVID-19" with a grammar violation. You can use a variety of portals (newspaper articles, official sites, social networks, including Facebook, etc.). Highlight the errors in red and suggest the correct variant in parentheses. Sentences can be emotional. Include the source of the information, the date of publication and the full link after the sentence. Make a PrintScreen sentence and paste it into the document.

Examples of the assignment can be selected by the teacher or the teacher may set the assignment in front of the student. Tasks can be formulated both concisely and with a detailed description.

"Theme. Features of Ukrainian language etiquette. Communicative qualities of language culture. Doctor's Language Etiquette": Task 1. What communicative feature (features) have been observed or violated in the text. The teacher offers texts on the issue of radio and television news: Заприсяглися Гіппократу. Черга Вітчизни. Випускники київських медичних вузів склали військову присягу на вірність україн- цям. Далі все менше лікарів обіцятимуть відданість і закону, і населенню. Згідно з постановою Кабміну від шостого року військові кафедри при українських вузах скорочують. План по офіцерах в запасі перевиконаний $(1+1,29.06 .2009, \mathrm{TCH}$, 19:37-38); У харківському обласному клінічному центрі урології та нефрології імені Шаповалова вперше в Україні провели унікальну операцію з видалення пацієнтці пухлини на єдиній нирці. Про це повідомляє прес-служба Міністерства охорони здоров'я. Єдина права хвора нирка була акуратно видалена із організму жінки і після спеціальної обробки та оперування поза організмом пересаджена за технологією трансплантації у ліву частину тіла пацієнтки. Унікальність методу дала позитивні результати. Таке хірургічне втручання $\epsilon$ одним із найскладніших у сучасній світовій онкологічній практиці, адже потребує спеціального медичного оснащення і спільної участі в оперуванні хірургів, трансплантологів та урологів - пояснює прес-служба (радіо “Мелодія”, 17.08.2012, Новини, 20:01-02).

We offer another task for this theme, but with a detailed description of the implementation: Task 2. Analyze the text for the presence/absence of communicative features.

Step 1. Find 2 pieces of text (messages) with the word "quarantine" ("карантин”) or "self-isolation" ("самоізоляція") on the Internet. You can use a variety of portals (newspaper articles, official sites, social networks, including Facebook, etc.).

Step 2. Type these sentences in Word (Times New Roman, size 14). If there are errors in the sentences, highlight them in red and in the parentheses suggest an edited variant.

Step 3. Type the source of information, the date of publication, and the full link.

Step 4. Make a PrintScreen and paste it into the document.

Step 5. What communicative features are in this text, what communicative features may have been violated? Explain your thoughts.

The research demonstrates that the teacher must take into account the goal, the age of the students, the professional orientation of the tasks. For example, during the coronavirus pandemic, it is very interesting to investigate the functioning of the lexemes "coronavirus" (“коронавірус") or "COVID-19. Thus, it is very important to use material that is timely, clear and relevant. 


\section{"PROFESSIONAL AND COMMUNICATION CULTURE OF THE FUTURE DOCTOR: LINGUISTIC, PEDAGOGICAL AND PHILOSOPHICAL ASPECTS”}

"Theme. Public speech and its genres": Task 1. Record a 3-5 minutes video on a suggested topic. Your presentation must be prepared in advance and delivered orally. Thus, we can evaluate the student's oratorical abilities, the completeness of the answer, the linguistic layout of the text, the orthoepic skills of the speaker.

It should be noted that during the distance learning each task should have a detailed instruction manual. After all, the student must clearly understand what is required of him. In addition, samples should be submitted for practical tasks. For example, the theme "Public speech and its genres" may include a video fragment of a sample speech. This approach to work will reduce the risk of misunderstanding between the teacher and the student.

It underscores that the given tasks have a practical orientation and cannot comprehensively assess the student's knowledge level in the study of a specific topic, but they aim to diversify distance learning, make it interesting.

\section{List of literature}

1. Веремчук А. Проблеми і перспективи дистанційного навчання у ВНЗ / А. Веремчук // Проблеми підготовки сучасного вчителя. - 2013. - № 7. - С. 319-325.

2. Кадемія М. Ю. Дистанційне навчання у віртуальному університеті як спосіб доступу до якісної освіти / М. Ю. Кадемія, В. О. Уманець // Відкрите освітнє е-середовище сучасного університету. - 2016. - № 2. С. $192-198$.

3. Прибилова В. М. Проблеми та переваги дистанційного навчання у вищих навчальних закладах України / В. М. Прибилова // Проблеми сучасної освіти. - 2013. № 4. - С. 27-36.

4. Про затвердження Положення про дистанційне навчання : наказ Міністерства освіти і науки України від

\section{References}

1. Veremchuk, A. (2013). Problemy i perspectyvy dystantsiinoho navchannia u VNZ [Problems and perspectives of distance learning in universities]. Problemy pidhotovky suchasnoho vchytelia - Problems of Training of a Modern Teacher, 7, 319-325 [in Ukrainian].

2. Kademiia, M.Ya., \& Umanets, V.O. (2016). Dystantsiine navchannia u virtualnomu universyteti yak sposib dostupu do yakisnoi osvity [Distance learning at a virtual university as a way to access quality education]. Vidkryte osvitnie e-seredovyshche suchasnoho universytetu - Open Educational E-Environment of Modern University, 2, 192198 [in Ukrainian].
Conclusions and Prospects for Research. In today's world, computer technology is a major instrument of cognition. Of course, they do not always have positive effects, however, as it turned out, during the unforeseen situations, such as the coronavirus pandemic, they played a role in favor of the education system. As a result, the usage of distance learning with computer technology has saved and ensured the learning process. Therefore, it is undisputed that the distance education system needs to be improved and developed.

It should be noted that distance learning itself encourages the specialist to search for new forms and methods of teaching the discipline, and the student to work independently, to work with different sources of information. It considers the development of distance learning in the Ukrainian education system is perspective. The actual direction of further work is the improvement of remote technologies and the development of set practical tasks in the relevant disciplines, which must correspond the current trends in the development of science.

25.04.2013 р. № 466 ; зареєстровано в Міністерстві юстиції України 30 квітня 2013 р. за № 703/23235.

5. Унгурян Л. М. Дистанційне навчання студентівзаочників фармацевтичного факультету в медичному ВНЗ / Л. М. Унгурян, Г. В. Чернецька, І. А. Науменко // Медична освіта. - 2013. - № 3. - С. 95-97. - https://doi. org/10.11603/me.v0i3.2200.

6. Хассон В. Дж. Критерії якості дистанційної освіти / В. Дж. Хассон, Е. К. Вотермен // Вища освіта. - 2004. № 1. - С. 92-99.

7. Штихно Л. В. Дистанційне навчання як перспективний напрям розвитку сучасної освіти / Л. В. Штихно // Молодий вчений. - 2016. - № 6. - С. 489-493.

3. Prybylova, V.M. (2013). Problemy ta perevahy dystantsiinoho navchannia u vyshchykh navchalnykh zakladakh Ukrainy [Problems and advantages of distance learning in higher educational establishments of Ukraine]. Problemy suchasnoi osvity - Problems of Modern Education, 4, 2736 [in Ukrainian].

4. The Ministry of Education and Science of Ukraine “On Approval of distance learning” 25.04.2013 No. 466, registered in the Ministry of Justice of Ukraine on April 30, 2013 by No. 703/23235 [in Ukrainian].

5. Unhurian, L.M., Chernetska, H.V, \& Naumenko, I.A. (2013). Dystantsiine navchannia studentiv-zaochnykiv 
farmatsevtychnoho fakultetu v medychnomu VNZ [Distance learning of part-time students of the Faculty of Pharmacy at a medical university]. Medychna osvita - Medical Education, 3, 95-97. Retrieved from: https://doi.org/10.11603/ me.v0i3.2200 [in Ukrainian].

6. Khasson, V.G., \& Woterman, E.K. (2004). Kryterii yakosti dystantsiinoi osvity [Quality criteria for distance education]. Vyshcha osvita - Higher Education, 1, 92-99 [in Ukrainian].

7. Shtykhno, L.V. (2016). Dystantsiine navchannia yak perspektyvnyi napriam rozvytku sychasnoi osvity [Distance learning as a perspective direction for the development of modern education]. Molodyi vchenyi - Young Scientist, 6, 489-493 [in Ukrainian].

E-mail address for correspondence: zalips_ija@tdmu.edu.ua 